\title{
SOCIETY AND RESOURCES OF INTELLECTUAL CAPITAL IN SOCIAL RELATIONS
}

\author{
Peter Plavčan $^{1}$
}

\begin{abstract}
The scientific-technical development of the world society is based on quickly developing information and communication equipment and technologies. The knowledge about the education society and its characteristics in the international context and the knowledge on the intellectual capital enable international comparison of the selected states of the world. The knowledge on the relation between intellectual capital and the costs to reproduce it also enables comparison between the individual states mutually and makes it possible to ponder the relation between the quality of education and the basic economic indicators, e.g., gross domestic product. The overview of selected statistic indicators describing the size of the intellectual capital and systemization of knowledge on intellectual capital from the point of view of the society as well as individual and the proposition of the opportunities to measure intellectual capital enable a more detailed focus on the intellectual capital topic and its importance for the world society and economy. The research results can be used as an argument for increasing expenditure on education in national economies.
\end{abstract}

JEL Classification Numbers: A13, H10, DOI: https://doi.org/10.12955/pss.v2.238

Keywords: intellectual capital, social system, social relations, tertiary education

\section{Introduction}

The fast scientific-technical progress at the end of the $20^{\text {th }}$ century has changes the nature of the work producing wealth, from the physical to the mental one. Suppose the economy of the previous centuries was based on work and capital. In that case, the economy of the $2^{\text {nd }}$ half of the $20^{\text {th }}$ century and the current economy of the beginning of the $21^{\text {st }}$ century is based on knowledge and modern information and communication equipment and technology. The term education economy or economics based on knowledge started to be used at the beginning of the 90-ties of the $20^{\text {th }}$ century (Drucker, 1994) and expressed the usefulness of the knowledge to produce economic benefit.

One could dispute and say that every social development is based on knowledge and its implementation in the production of the individual societies from the primitive communal society until now. As we perceive the knowledge society and knowledge economy, we emphasize current fast knowledge progress in practically all the spheres of scientific knowledge and the way of processing and using this information in a real-time for the purposes of human society. That is why we call the current society "knowledge society" and the current state of economics "knowledge economics".

In the paper, we rely on the thesis that in the current COVID-19 world society, the education system and preparation of a qualified workforce for the labor market is one of the most endangered spheres of society. The transfer to online education decreases direct contact between the provider of education and the students, while endangering the quality of provided education and many fields require except provided education and practical skills to perform the occupation. Such practical skills are under current circumstances of reduced movement of people in public and in institutions cannot be achieved. The paper is based mostly on theoretical analysis. Its results have a potential value for further research in the economics of education. The main research methods in this paper are special methods used in the context of educational sciences. The historical-logical analysis of the economics education, the method of analogy, the transfer of the basic principles of the educational sciences to the Slovak and world economy are used.

\section{Goals and methodology}

This paper aims to present knowledge on knowledge society and its characteristics in the international context and currently on intellectual capital according to the education level of the inhabitants in the selected states. The paper focuses on both levels of technical education, being secondary and tertiary education as main disposable parts of the intellectual capital and its carrier, the qualified professional. A part of technical education that prepares theoretically and practically for the practising of the vocation is also secondary education. That is why knowledge on the relation of the intellectual capital is being presented, but also the costs to reproduce it and the knowledge on the intellectual capital from the point of view of the individual. One of the paper's goals is to describe the findings of quantity and quality of

\footnotetext{
${ }^{1}$ Danubius University, Faculty of Social Studies, Sládkovičovo, Slovakia, peter.plavcan@ vsdanubius.sk
} 
the intellectual capital and on findings of the application of the intellectual capital of the individual on the labor market in the individual national states.

The research problem of this paper is the collection and systemization of knowledge on intellectual capital from the point of view of the society and from the point of view of the individual and the proposition of the possibilities to measure intellectual capital of the society. The paper is based mostly on theoretical analysis. Its results have a potential value for further research in the economics of education. The main research methods in this paper are special methods used in the context of educational sciences. The historical-logical analysis of the economics education, the method of analogy, the transfer of the basic principles of the educational sciences to the Slovak and world economy are used.

\section{Results}

\section{Knowledge economy and intellectual capital}

There are many theories on capital containing its definitions e.g., "capital are goods that produce further goods", so one of the Nestor of Slovak banking and one of the "fathers" of the miracle of Slovak economics in the $20^{\text {th }}$ century (Karvaš, 1947). However, there are many different theories. In general, to produce products (of material nature - products and immaterial nature - services) one needs capital. Capital can therefore be of material, financial, and human nature, while we think that this sorting of capitals is the simplest one, but also sufficient for our reflections about intellectual capital. Each of the aforementioned natures of the capitals has its specifics.

The basic condition of the prosperity of any society, therefore of enterprise, region, community, state in the current global world society, is also a creation of the plentitude of material sources in order to provide for its needs. In the condition of continually quickening scientific-technical progress and rapidly changing global world capital and labor market, it is fundamental to apply economic policy encouraging to the high level of economic effectiveness. The effectiveness of the economy and its sectors and fields is currently brought only by production with high participation of creative human work that is embodied in the new products - innovations. The application of the economic policy supporting innovations is a further condition for the establishment and existence of a knowledge economy.

The most significant negative consequences of the knowledge economy requirements for the workforce are mainly: the deterioration of the interchangeability of employees on their working positions, which when then production is changing frequently causes their redundancy or the deterioration of their success on the international, but also domestic labor market, although their technical qualification is often high. In parallel, it might create conflicts between the groups of employees whose social position in the knowledge economy resulting from qualification will not be equal.

The continuous learning in knowledge economy is therefore a lifelong necessity for the workforce who will have to make more and more effort to achieve it and consequently sustain their position on the international and national labor market. This learning during all of the productive years is called advanced training and increasingly becomes a decisive part of lifelong learning to pursue required competencies of the workforce that are also required by the labor market.

\section{Human capital requirements in the knowledge economy}

The transition from the industrial economy to knowledge economy requires great support of human resources development. Without so-called innovators, it is impossible to fulfill the intentions of the wellprocessed national social and economical strategy to increase innovation in society and economy, nor to perform necessary research and development or to implement new modern informational and communication techniques and technology.

In the knowledge economy in the run of $21^{\text {st }}$ century, we presume the following development of requirements of human capital:

Furthermore, the share of costs for the qualified workforce from the overall production costs will increase because of the growing materialization of the education into the technical level of production means.

Furthermore, the effort to sustain the mass effect in education as well as the effort to continue learning for the whole life - lifelong education, mass effect, and continuity will furthermore be a basic premise to create the equality of the chances for the individuals, but it also is a premise for the creation of the 
highly educated elites and decrease of the impact of the aging of the population in the industrially mature states.

Furthermore, the preparation for the occupation will be transferred to the later levels of education. If at the end of $20^{\text {th }}$ century, middle education was a decisive level of theoretical and practical preparation for the occupation (fields of study in the vocational and middle special schools). At the beginning of the $21^{\text {st }}$ century, the university level of education becomes decisive for achieving the required qualification to perform more and more occupations and specialized activities.

The variety of content and institutions in the education will continue to broaden up - various educational ways will be introduced. Relevant authorities will start to accept knowledge learned informally and formally to continue the studies and perform occupational and vocational activities.

Division of the available workforce into less qualified workforce performing mainly manual works and into more qualified workforce, so-called "knowledge workers" (Drucker, 1994, 2), where the tertiary education will continuously become basic and inevitable qualification premise for their success on the international and national labor market. The part of the qualification of such workforce is the complete knowledge system composing of two parts, of general theoretic knowledge and of the specific specialized knowledge, ability to independently solve technical problems, ability to communicate in more languages, and the ability to act with social and cultural empathy. The knowledge economy requires for the global activity of international business subjects fitting peaceful, friendly, safe, and geopolitically fitting environment.

In tertiary education, the provision of doctoral studies will become more frequent, the engagement of post-doctorates and performance of post-doctorate activities will be increased. The increasing tendencies of the education level of the decisive part of the workforce establishing a basis for human resources needed to develop the economy starting with middle education after the $2^{\text {nd }}$ world war until the third degree of university education in the first half of the $21^{\text {st }}$ century, the growth of the universityeducated inhabitants in the population is an inevitable requirement of the intellectual capital growth in the society, therefore, conditioning its prospect.

We furthermore think that the difference in the income of the "copying" workers and those providing for innovations.

The binary system of tertiary education rendered by the university and non-university colleges will keep developing and sustaining, despite various reform efforts, e.g., reform of the British tertiary system at the end of the $20^{\text {th }}$ century, where the non-university colleges changed to university ones and a closer connection between university colleges and social, mainly industrial practice has been created, however, it will always be necessary to modify the ratio between the share of theory and practice in the content of the university education for the purposes of the qualified performance of the occupations requiring university education as a part of the qualification, but also a theoretical part of the current content of university education, which requires highly sophisticated preparation, where it was not needed ten years ago, mainly because of the implementation of modern technology and communication means into the performance of occupations, where it was not usual before, e.g., social work.

The support of private tertiary education by business subject will increase because the applied research is being done for their needs while preparing people for particular specialized technical activities that the labor market requires and is a subject to their entrepreneurial interest - tertiary education belong to the most risky sectors of the economy on the long run.

Every innovation requires concentration of the highly qualified workforce resulting in bigger creation of the mobility and concentration possibilities (excellence centers), which will induce greater effort to remove barriers in capital mobility in all its natures and consequent increase of costs for every innovation will in parallel result in greater effort to protect intellectual property.

Furthermore, the creation of information knowing communities in the national and international organization, in which their member participate in voluntary knowledge exchange led by their own interest or target-oriented one, in the relevant field of knowledge (Cohendet, 2005), then the search for ways to extend the trust of an individual when exchanging knowledge (cognitive distance) in the knowing communities (Nooteboom, 2000), mainly in the communities of practice exchanging knowledge in the practically performed activities, will continue (Wenger, 1998). 
The effort to create formal knowing communities, mainly on the highest levels of society organizations, mainly recreation of national states or politically economic associations of national states (e.g., European Union) to knowledge economies as well as will continue the increase in profit from human capital activities in the economically more developed states and rich northern states with sufficient free financial sources to finance the education and flow of qualified workforce and its concentration and will furthermore continue the consequent increase in differences between the economically less and more developed countries. This is also connected with so-called: "brain drain" and with positive externality of the creation of mass knowledge potential to create quick and sophisticated results of creative activity, but also with negative externality, meaning leave of qualified workers, scientists, academics, and further groups performing sophisticated work on the labor market to the northern states where they will be able to valorize their work better than in their state of origin.

The attractiveness of the basic research will continue to increase, and one can await increasing requests for the gain of new knowledge in the form of new laws or theories as sources of new non-traditional solutions to problems of human society despite the current preference of applied research as a source of innovation economy, whose possibilities are restricted when compared to basis relevant research (e.g., theoretical clarification of gravity with the highest probability will lead to significant revolutionary changes in the field of aero-technology and consequently to the changes in the aero industry and associate fields, etc.)

The possibilities of the global world today are so big that the incorrect decision as for content or speed, e.g., in economics, has an instant negative consequence, which not only reflects in the economy itself but also in many further economies of national states from all around the world with a big material and immaterial impacts on society, communities, and individuals. The current world crisis induced by COVID-19 refers to such an impact on world society.

After knowledge society, we can expect probably a society o quick decisions. The knowledge society and all of their preceding societies have various characteristics; however, what they do have in common is that they all are characterized by means of economic relations in the human society and by the level of development of production means of material natures that are determining for classification of the individual social-economic formation. The knowledge society is characterized mainly by the knowledge of immaterial nature and social relations in human society (Plavčan, 2020).

Further possible society of quick decisions, however, will need be able not only to quickly recognize and define social phenomena and their cause - lower concurrent processes but also to detect complex causality of social phenomena with a huge mass of knowledge, to evaluate these and to be able to decide quickly - higher convergent processes, to use the created richness to the benefit of human society so that this decision doesn't bring any lateral negative effects. Our reflection on the future of human society results from the mutual human trust that the human ambition and aspiration to extend knowledge is overtaken by other ways of social existence, even in the form of consumption society, but also by the frustration from the complexity of the economic world of asocial relations. Also, in the current society, we can find examples in the world and life of some communities and individuals e.g. return to nature.

\section{Intellectual capital and world society}

The knowledge economy combines general requirements for society and economic development and the national specifics. The general requirements for the development of society are connected with the transition of the signs of globalization of the world economy to the national economies. The individual national states have different default states of development, differently stated of the development of fields and areas of the economy, social position and cultural development of the inhabitants, various states in the field of available human resources, various natural resources and state of the environment and further differences. Therefore, the individual national states have to look for their own nationally directed strategies and policies of own development in compliance with world trends of the development of individual fields in scientific and technical politics.

The following can be interpreted from Table 1 on quantity and quality of intellectual capital:

Costs spent for universities from the gross domestic products in percent and cost for one student are not mutually intertwined, we register states with higher university costs of gross domestic product and average costs for one student and vice versa, 
Costs spent for universities from the gross domestic product in percent and share of the public sources on the university costs in percent are obviously mutually not intertwined. In the states with a high percentage of public sources share on university costs, they have higher, average, and even lower percentage share on university costs from gross domestic products.

\begin{tabular}{|c|c|c|c|c|c|}
\hline State & $\begin{array}{c}\text { Costs } \\
\text { per } \\
\text { student } \\
\text { in USD }\end{array}$ & $\begin{array}{c}\text { Costs per } \\
\text { universities } \\
\text { As \% from } \\
\text { HDP }\end{array}$ & $\begin{array}{c}\text { Percentage of } \\
\text { public } \\
\text { sources } \\
\text { within } \\
\text { university } \\
\text { costs } \\
\end{array}$ & $\begin{array}{c}\text { Percentage of } \\
\text { university- } \\
\text { educated people } \\
\text { within the } \\
\text { population } \\
29 \text { - 34-year-olds } \\
\end{array}$ & $\begin{array}{c}\text { Percentage of } \\
\text { university- } \\
\text { educated people } \\
\text { within the } \\
\text { population } \\
25 \text { - 64-year-olds }\end{array}$ \\
\hline Ireland & 16794 & 0.9 & 67 & 70 & 60 \\
\hline Canada & 24671 & 2.3 & 54 & 63 & 59 \\
\hline $\begin{array}{l}\text { Russian } \\
\text { Federation }\end{array}$ & 8629 & 1.1 & 66 & 62 & 57 \\
\hline Japan & 18839 & 1.4 & 31 & 62 & 52 \\
\hline Luxemburg & 52089 & 0.5 & 89 & 55 & 52 \\
\hline USA & 33063 & 2.6 & 35 & 52 & 49 \\
\hline Australia & 20436 & 2.0 & 36 & 52 & 48 \\
\hline United Kingdom & 28144 & 2.0 & 25 & 52 & 47 \\
\hline Finland & 17730 & 1.6 & 92 & 42 & 45 \\
\hline Iceland & 16270 & 1.3 & 90 & 47 & 45 \\
\hline Switzerland & $\mathrm{n}$ & $\mathrm{N}$ & $\mathrm{N}$ & 53 & 44 \\
\hline Lithuania & 8428 & 1.0 & 64 & 55 & 44 \\
\hline Belgium & 19422 & 1.5 & 82 & 47 & 41 \\
\hline Estonia & 14580 & 1.5 & 72 & 43 & 41 \\
\hline Denmark & 18062 & 1.7 & 99 & 47 & 40 \\
\hline France & 16952 & 1.5 & 77 & 48 & 39 \\
\hline Latvia & 8346 & 1.1 & 60 & 44 & 35 \\
\hline Austria & 19089 & 1.7 & 91 & 42 & 34 \\
\hline Germany & 18486 & 1.2 & 83 & 33 & 30 \\
\hline Portugal & 11788 & 1.2 & 60 & 37 & 26 \\
\hline Slovakia & 11715 & 1.0 & 68 & 39 & 26 \\
\hline Czech republic & 11484 & 0.9 & 73 & 33 & 24 \\
\hline Saudi Arabia & $\mathrm{n}$ & $\mathrm{N}$ & $\mathrm{N}$ & $\mathrm{n}$ & 24 \\
\hline Italy & 12226 & 0.9 & 62 & 28 & 20 \\
\hline South Africa & $\mathrm{n}$ & $\mathrm{n}$ & $\mathrm{N}$ & 6 & 7 \\
\hline
\end{tabular}

Note: As for percentage of the university educated people within population aged 25 - 64-and 29-34 (2019) we include absolvents of short university cycles, bachelor, master and doctoral studies or its equivalents

Source: OECD (2020, 1). Tab A1.1. C1.1., C2.1., C3.1.

The percentage of university-educated from a population of 29-34 year-olds is higher than the percentage connected to the fulfillment of one of five goals in education as defined in Lisbon strategy 2020 and in connection to the setup of measure leading to its fulfillment at the beginning of the first decade of the $21^{\text {st }}$ century.

The growth of intellectual capital by means of the growth of quota of university-educated population in the age group of 29-34 - year-olds creates bigger premises for the development of the knowledge economy.

The knowledge economy, irrespective of their future branch priorities, will inevitably require growth of intellectual capital in the structure of workforce with an increasing level of university education oriented on general preparedness of population in the field of information and communication technologies, its ability to continuously innovate their knowledge in this field by means of advanced training within lifelong education.

\section{Intellectual capital from the point of view of the individual}

The knowledge economy creates opportunities for the development of the individual with his ambitions and aspirations. The individual in the market economy conditions strives to use his work force as good 
as possible on the labor market and therefore participates in cultivation of his own intellectual capital, but also of the intellectual capital of the whole society. The way of cultivation of own intellectual capital of the individual is his own development that in the meaning of employers consists mainly of technical knowledge and practical skills to perform specialized technical activities in a particular organization, sustainable high performance, and initiative including working overtime, satisfaction from the performed activity, continuous education in the field of practice, ability to socially interact with coworkers in order to create progressive human relationships, ability to sustain good health, new requirement resulting from the company culture and business subject.

General requirements of the individual's labor market have their community, regional, and national specifics. These specifics reflect various state of material as well as personal resources. Also, employers have their requirements, specifics, and preferences for the individual from the point of view of individual sectors and fields of economy and from the point of view of their knowledge and work skills.

Directed creation, development, usage, and valorization of knowledge, so-called intellectual capital is of decisive importance for the organizations as for the sustainability of their development as well as gaining and sustainability of the competitive benefit. During recent years, we can witness significant growth of the importance of intellectual capital and its establishment as the most important form of capital. The intellectual capital is a basis for knowledge management and includes relations with organization partners, innovation effort, organization infrastructure, knowledge of their employees (Šebestová, 2010).

The intellectual capital belongs to the basic values of the organizations that the employees of the organizations have to respects. Suppose the employees share or accept these values. In that case, great synergic effects emerge, which make the organization balanced as for the interpersonal relations and has a big influence on its overall competitiveness and innovatory tendency (Šebestová, 2019).

In the market economy, the most significant factor deciding on the success of the individual in the labor market is his qualification. The qualification composes of more parts, the first and most important one is education and its level and content, further parts of qualification are further qualification requirements, e.g., proving the compliance with requirements for the performance of specialized activities, duration of technical practice - performance of occupation during a certain period of time, potentially under the lead of qualified member of the industry, membership in professional interest and labor chambers or other similar member organizations and further parts of qualification. The second most significant part of qualification is the technical practice performed on the labour market. Under technical practice we understand the performance of occupation or specialized activity of the employee with the employer at the position corresponding with his/her technical education. Technical education is a theoretical and practical preparation for the occupation. In the Slovak Republic, one gains such education by absolving studies at high school or college.

Therefore, the individual national states have to seek their own nationally directed strategies and tactics to develop intellectual capital from the individual's point of view. On one side, it is the state's task to by means of minimum wage and employer environment, e.g. by means of wage and employee benefits to create fitting conditions for the individual. This is in order for a job offer to be attractive for the individual or in order for him to find such a labor market that will enable him to valorize his qualification.

Along with all of the qualification components, maybe the most important part except for technical practice is education. As proven in the presented overview, the level of achieved education has the most significant influence on the height of personal income of the individual on the international labor market. In the following table, the average incomes of individuals in the selected states of the world are states, whereas specific attention is being paid to European Union member states in the age group of 25-64year-olds.

From Table 2, a few consequences about the application of intellectual capital of the individual on the international labor market can be drawn as follows:

The biggest difference between the average labor prices of an individual with basic and university knowledge is in the USA. This fact confirms the known preferences of the inhabitants to achieve the education of the best quality and the highest level. This also brings pressure to increase the height of the 
tuition because the demand for education is high, and so is the indebtedness of the young generation in the USA (the highest in the world) in connection with student loans

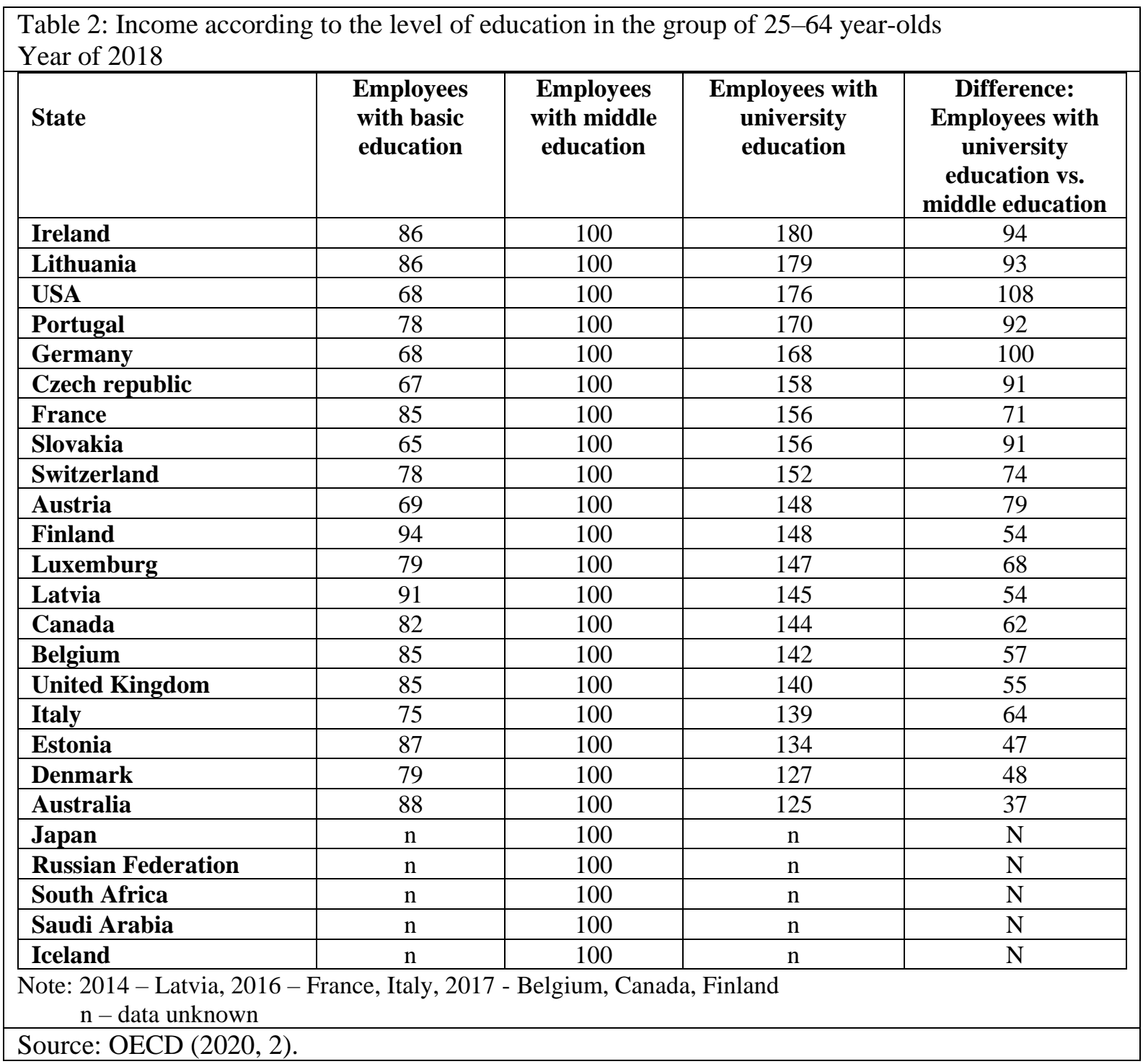

Following states belong to the states with the high difference between the average labor price of an individual with basic and with university education: the industrial world states (Germany), but mainly the states of Central and Eastern Europe, where the transformation of the economy toward the change of the field structure and towards work productivity in the economy (Lithuania, Czech Republic, Slovakia) is still happening

As for the states with the slightest differences between average labor price of an individuals with the basic and university education, here belong industrially developed world states (United Kingdom, Denmark, Australia), and states, where the economic transformation is still running (Estonia, Latvia).

The searching of the intellectual capital from the individual's point of view belongs to the basic research fields of economic theory and their results presume significant base of date for the decision-making of the management sphere.

\section{Discussion}

Following conditions are therefore defined as basis for the establishment and existence of the knowledge economy (Plavčan, 2020): significant increase of social cognition, lasting quantitative and qualitative development of human capital, support of science, creation, and development of social economy in the society and implementation of economic policy supporting innovations.

The significant basic conditions for the establishment and existence of the knowledge economy create special and difficult requirements for the qualification of the workforce. The knowledge society requires 
from the following from the workforce: continual growth of technical knowledge and work skills, habits and crafts, lifelong learning, increase in specialization, an increase of national and international mobility, and ability to cooperate.

The workforce with the tertiary education will be more and more clearly divide into workers who perform more or less complex activities requiring a certain level of independence and creativity and ability to handle technical equipment on the current level of scientific-technical development and those who will perform easier reproduction of technical skills - so-called copying the group of less people performing highly qualified work requiring a high level of creativity that disposes of skills to create new knowledge and performing difficult mental, technical activities - extended reproduction of technical activities - innovations.

The current general lack of qualified specialists in the world would be able to perform complicated, sophisticated work and decrease interest in studying natural sciences and technical studies, which will create obstacles in the future in creating a knowledge economy.

The knowledge on the relation between the intellectual capital and costs to reproduce it also enable comparison between the individual states mutually, but can also ponder the relation between the quality of the education and the basic economic indicators, e.g., gross domestic product and others. (Plavčan, 2019). Similarly, Hanushek says that there are some connotations between education and economic parameters (Hanushek, 2016).

\section{Conclusion}

The information on the knowledge society in the international overview of the selected states of the world and parallel on intellectual capital according to the education level of the inhabitants not only brings information on the current state but also enables international comparison between the individual states mutually and can serve as an impulse to intervene in education policies.

In the current world society, the education system and preparation of a qualified workforce for the labor market belong to the most endangered fields of society during the COVID-19 period throughout all continents. The paper not only presents theoretical knowledge on intellectual capital from the point of view of the society and the individual but also proposes possibilities to measure intellectual capital by means of the education level of the inhabitants.

Therefore, the analysis results can be used as an argument to support the decisions of state authorities based on increasing expenditure of education, which indirectly, as one of the factors, bring economic growth. Further research will focus on the sectoral analysis of the relationship between educational attainment and sector growth.

\section{References}

Cohendet, P. (2005). On knowing communities. Draft Paper for the Conference Advancing Knowledge and the Knowledge Economy, 10-11 January 2005 at the National Academies, Washington.

Drucker, P., F. (1994). Věk diskontinuity - obraz měnící se společnosti [The Age of Discontinuity - A picture of a changing society]. Praha: Management Press.

Hanushek, E. A. (2016). Will More Higher Education Improve Economic Growth? Oxford Review of Economic Policy, 32 (4), 538-552.

Karvaš, I. (1947). Základy hospodárskej vedy 1, 2 [Basics of economic science 1, 2]. Martin.

Nooteboom, B. (2000). Learning by Interaction: Absorptive Capacity, Cognitive Distance and Governance. Journal of Management and Governance, 4.

OECD (2020). Education at a Glance. oecd.org/education/education-at-a-glance/

OECD (2020). OECD.Stat. stats.oecd.org/Index.aspx?DataSetCode=EAG_EARNINGS

Plavčan, P. (2020). Sociálna a vedomostná ekonomika [Social and knowledge economy]. Brno: MSD. ISBN 978-80-7392$352-5$

Plavčan, P. (2019). The comparison of PISA educational results with gross domestic product in member states of the European Union. Prague: International Conference on Innovations and Science education. March 20-22, 2019. In Journal Contact. Print ISSN 1805-997X, Online ISSN 1805-9961.

Šebestová, P. (2019). Teória a prax manažmentu kvality sociálnych služieb [Theory and practice of quality management of social services]. Brno: MSD. ISBN 978-80-7392-320-4

Šebestová, P. (2010). Základy celostného manažmentu sociálnej práce [Basics of holistic management of social work]. Sládkovičovo: VŠD. ISBN 978-8089267-41-5

Wenger, E. (1998). Communities of Practice: Learning as a Social System. Systems Thinker, 9/5. 